\title{
Drugs Use by Adolescents and their Perceptions about Specialized Treatment Adherence and Dropout ${ }^{1}$
}

\author{
Gabriela Pereira Vasters ${ }^{2}$ \\ Sandra Cristina Pillon ${ }^{3}$
}

Drugs use in adolescence is an important issue to be discussed, due to the early damage it causes. This study investigated adolescent drugs use, ranging from the first trial to perceptions about treatment adherence. Based on qualitative research, the researchers aimed to understand the problem from the subjects' viewpoint. Data were analyzed through thematic categorization. Fourteen teenagers were interviewed: mostly males, 14 to 19 years old and low education. Marijuana was the most used drug upon the first trial. Friends, free time and "parties" favored drugs use. Teenagers also used drugs to escape from conflicts and feelings. Different intrinsic and extrinsic factors were reported as favorable to treatment adherence and dropout. The findings can contribute to establish therapeutic intervention proposals for adolescent drug users.

Descriptors: Street Drugs; Adolescent; Substance Abuse Treatment Centers; Patient Dropouts.

\footnotetext{
${ }_{1}^{1}$ Paper extracted from Master's Thesis "Trajetória dos adolescentes usuários de drogas de um serviço especializado: do primeiro uso ao tratamento", presented to Programa de Pós-graduação em Escola de Enfermagem de Ribeirão Preto, Universidade de São Paulo, WHO Collaborating Centre for Nursing Research Development, SP, Brazil.

2 Occupational Therapist, Master's Student in Nursing, Escola de Enfermagem de Ribeirão Preto, Universidade de São Paulo, WHO Collaborating Centre for Nursing Research Development, SP, Brazil. E-mail: gabi_vasters@yahoo.com.br.

${ }^{3}$ RN, Ph.D. in Sciences, Associate Professor, Escola de Enfermagem de Ribeirão Preto, Universidade de São Paulo, WHO Collaborating Centre for Nursing Research Development, SP, Brazil. E-mail: pillon@eerp.usp.br.
} 


\section{O uso de drogas por adolescentes e suas percepções sobre adesão e abandono de tratamento especializado}

O uso de drogas na adolescência é questão importante a ser debatida pelos prejuízos ocasionados precocemente. Neste estudo objetivou-se conhecer o uso de drogas entre adolescentes, da primeira experimentação às percepções sobre adesão ao tratamento, com base na pesquisa qualitativa, e se buscou essa compreensão através do ponto de vista dos sujeitos. Os dados foram analisados por categorização temática. Quatorze adolescentes foram entrevistados: maioria do sexo masculino, idade entre 14 e 19 anos e baixa escolaridade. Maconha foi a droga mais utilizada na primeira experimentação. Amigos, tempo livre e "festas" favoreceram a aproximação às drogas. Essas também foram utilizadas pelos adolescentes como escape dos conflitos e sentimentos. Diferentes aspectos intrínsecos e extrínsecos foram referidos como favoráveis à adesão e abandono do tratamento. Os achados podem contribuir para a elaboração de propostas de intervenções terapêuticas, direcionadas a adolescentes usuários de drogas.

Descritores: Drogas Ilícitas; Adolescente; Centros de Tratamento de Abuso de Substâncias; Pacientes Desistentes do Tratamento.

\section{Uso de drogas por adolescentes: sus percepciones sobre adhesión y el abandono del tratamiento especializado}

El uso de drogas en la adolescencia es una cuestión importante a ser debatida por los perjuicios ocasionados precozmente. El estudio objetivó conocer el uso de drogas entre adolescentes, partiendo del inicio del uso hasta las percepciones sobre la adhesión al tratamiento. Basándose en la investigación cualitativa, se buscó comprender los aspectos citados desde el punto de vista de los sujetos. Los datos fueron analizados por categorización temática. Catorce adolescentes fueron entrevistados, la mayoría era del sexo masculino, con edad entre 14 a 19 años y baja escolaridad. La marihuana fue la droga más utilizada en la primera experiencia. Amigos, tiempo libre y "fiestas" favorecieron la aproximación con las drogas; estas también fueron utilizadas por los adolescentes como fuga de los conflictos y sentimientos. Diferentes aspectos intrínsecos y extrínsecos fueron referidos como favorables a la adhesión o al abandono del tratamiento. Los hallazgos pueden contribuir en la elaboración de propuestas de intervenciones terapéuticas direccionadas a adolescentes usuarios de drogas.

Descriptores: Drogas Ilícitas; Adolescente; Centros de Tratamiento de Abuso de Sustancias; Pacientes Desistentes del Tratamiento.

\section{Introduction}

As from the most recent government period, the Ministry of Health has fully and articulatedly assumed the challenge of prevention, treatment and adequate rehabilitation for alcohol and other drugs users as a public health issue ${ }^{(1)}$, according to the emphatic suggestion that resulted from the III National Mental Health Conference, held in 2001. The law determines that people seeking treatment for drugs use should be offered care options, so as to guarantee comprehensive and effective treatment, including specific care delivery to children and adolescents who need such interventions ${ }^{(2)}$.

Adolescence is a period marked by the changes and adaptations people go through in the transition to adult life. It is considered a critical phase in terms of personal and interpersonal competency development, skills acquisition and decision making(3). Besides, it is during adolescence that subjects more strongly seek their universe of experiments (discovery of what is new) and identifications, generally associated with the peer group. Drugs consumption among adolescents has been 
expanding in current society. This use has occurred early and, hence, its consequences or harm can also be anticipated.

Different meanings or motives exist for the start of drugs use nowadays, as different ways of relating to drugs can be established, so that who consumes or tries them out does not always develops some addictionrelated problem. Throughout history, psychoactive substances have been inserted in different cultures, permitting several bonds. Literature has identified that most adolescents consume alcoholic beverages for "social" reasons and mention little on coping as the mean reason for this use ${ }^{(4)}$, although studies appoint different other motives for consumption, including the search for pleasure, fun, experimentation/curiosity, social valuation/belonging, relief of boredom, relaxation, as well as personal problems ${ }^{(5)}$.

Despite the apparent rise in the demand for specialized treatment places as a result of increased drugs consumption, a study at public institutions working in care delivery to drugs users found that there is no lack of places for care delivery to this population, that is, places are available to treat drugs abuse or addiction in specific services. The author reported that services have no estimates on the number of young people who would need care. This lack of data does not permit knowledge on the actual demand for new specialized services ${ }^{(6)}$.

In all specialized drugs treatment models, individuals can get involved in or drop out, i.e. not adhere to the proposed treatment. Although some authors define "adherence" as remaining abstinent from the used substance(7), one can go beyond and suggest that treatment adherence involves the establishment of bonding between service user and health team, so that a mutual commitment exists in treatment activities, thus favoring changes in drugs use behavior.

Literature appoints that adherence to psychoactive drugs addiction treatment remains a challenge, which has showed to be even greater among adolescents, as addressed in different studies $^{(8-10)}$. What can be observed in institutional practice and is supported by literature is that young people hardly seek any kind of drugs addiction treatment and that, when they do, often drop out early(11), i.e. before the treatment enhances any effective changes.

In view of the current relevance of this theme (adolescent drugs use and specialized treatment), the goal of this study was to get a brief picture of adolescents' trajectory in specialized drugs use treatment, in the attempt to identify their general characteristics, drugs use-related aspects, how these adolescents reached specialized treatment and how they perceive the factors that facilitate or hamper their continuation in treatment.

\section{Methods}

The methodological option is based on a qualitative research branch, aimed at understanding human beings' acts and behaviors by prioritizing the research subjects viewpoint $^{(12)}$.

As a data collection instrument, a semistructured interview script was used, elaborated based on the proposed objectives. In principle, a pilot study involving four subjects was carried out to test the interview script. These interviews helped us to identify the necessary adjustments and adaptations. The script covered the following items: characterization of research subjects, aspects related to adolescents' daily reality (school, work, leisure), to the first trial, continuous drugs use and specialized treatment. The interviews were previously scheduled and held at the adolescents' homes. The participants' general characteristics were described. Other information was analyzed based on thematic categorization.

The ethical aspects established in the Guidelines and Regulatory Standards for Research involving Human Beings $^{(13)}$ were guaranteed in this study. Approval was obtained from the Institutional Review Board at the University of São Paulo at Ribeirão Preto College of Nursing under protocol No 0859/2007.

The adolescents in this study were contacted through a Psychosocial Care Center for Alcohol and Drugs II (CAPS-ad II) in the interior of São Paulo, established and regulated based on Law 10.216, issued on April $06^{\text {th }}$ 2001, which rules on protection and rights of mental disorder patients, thus redirecting the mental health care model(14).

The following criteria were used to include the subjects in the research: adolescents (between 12 and 18 years old at the start of treatment) who participated in at least two activities offered by specialized treatment, living in the city where the service was located, who voluntarily accepted to participate in the research after receiving information about the aims and ethical aspects (or, in case of minors, who received authorization from the responsible family member to participate in the study), and without cognitive problems that would hamper their understanding of the questions. 


\section{Results and Discussion}

Study subjects were fourteen adolescents. Eight of them were participating in therapeutic activities, while six had dropped out. Eleven adolescents were male. Ages ranged from 14 to 19 years. The latter had started treatment at the age of 18 .

A for the adolescents' general characteristics, five lived with a biological close relative, i.e. parents and siblings or not. Two adolescents reported living with their non-biological close family, i.e. mother, stepfather and siblings. Seven of the interviewees lived with only one of the parents, six with their mother and one with their father. Other members identified in the family composition were sister-in-law, grandmother, wife and child. The predominant family composition among the adolescents was mono-parental, which literature appoints as one of the factors that enhance drugs use, although it is not considered a determinant factor for consumption(15). We highlight the need to discuss new family configurations in literature as a part of these and so many other adolescents' current context.

Regarding education, only four adolescents were taking the grade that corresponded to their age: the remainder was in a grade considerably lower, in line with literature on the existing relation between low educational performance and drugs use ${ }^{(16)}$. Seven participants were attending school on a regular base, two had finished secondary education and five had stopped studying.

Half of the interviewed adolescents had some kind of paid job, but only one of them performed this activity formally. Only one adolescent studied and worked, and another neither worked nor studied. The other participants were inserted in either one activity or the other, i.e. they studied or worked. In general, one choice is observed to the detriment of another as, although all adolescents are of school age, some contexts demanded early work. In this respect, the need to work, generally badly paid and without guaranteed rights, tends to replace the conclusion of education, and the consequent lack of qualification ends up hindering professional ascent and access to better wages.

The relation between low educational performance or school drop-out and drugs use has been repeatedly discussed in literature, and is also perceptible among the study participants. In this case, the exclusion of formal education can eliminate school as an access route for drugs prevention policies(17), although a study revealed that adolescents did not perceive school as a protection factor $^{(18)}$.
About drugs use, the age of the first illegal drugs trial ranged between 12 and 16 years, with 13 years as the prevalent age among the study subjects. For the interviewed adolescents, the use of marijuana (eleven subjects) and ethyl chloride recreational inhalants (one subject) occurred at younger ages; adolescents who started using cocaine (two subjects), on the other hand, were older than those who first used other drugs (between 14 and 15 years). These data are in accordance with epidemiological surveys regarding age(19), although the interviewed adolescents started trying out illegal drugs, differently from the legal drugs found in this survey.

Except for one adolescent who reported being alone during his first trial, the remainder was accompanied by one or more friends, or by family members. In view of these data, peer group and family participation in the first drugs use should be taken into account as part of the search for new models of conduct or even as an incentive for new experiences characteristic of adolescence, as friends were identified in literature as the main sources of influence towards drugs use, followed by influence from family members ${ }^{(20)}$.

Regarding continuous drugs use and specialized treatment, the adolescents' reports were described as thematic categories, divided in sub-categories as presented next.

\section{Motives for continuous drugs use}

Four sub-categories were found related to the motives for continuous drugs use, which were "daily reality, fun, occupying free time", "management of conflict situations", "dealing with feelings" and "different benefits". To justify continuous drugs use, the adolescents' statements revealed an intense relation between the use of free time, leisure activities and drugs use.

In these adolescents' experience, we highlight that the lack of motivating activities, which enhance personal development or provide pleasure and fun (either through play, cultural or sports activities), and the restriction of such moments of fun to "social events" (parties) seems to be related with greater drugs consumption. This permits various reflections on true leisure possibilities in certain contexts, different from parties or the streets, or even on how effective it is to direct activities during free time without addressing issues like choices, group pressure or stress relief.

The lack of skills for conscious and healthy coping with conflict situations(21), as well as inability to deal with feelings like "anxiety" or "depression" were presented as motives for continuous use. This is one of the challenges 
of specialized treatments, i.e. to equip the adolescents who seek these treatments to solve adverse situations, so that drugs are not the only alternative or escape from reality. Among the abovementioned benefits to explain continuous drugs use, the pleasurable effects and wellbeing the drug enhances were reported, as well as that of "raising appetite". These effects could be addressed together with the adolescents, seeking alternatives for these aspects.

\section{Desire or intensity of use}

The adolescents mentioned some aspects as factors enhancing their desire or intensity of drugs use, which were: free time, company, places or situations (parties), personal problems (parents' separation, death), feelings (anger, solitude, anxiety), addiction/usage routine. Again, the contribution of aspects related to free time is observed, as well as company of drugs-using friends and social events as factors that can act to increase the desire/intensity of drugs use.

\section{Motives for changes in drugs consumption patterns}

Regarding motives for changes in usage patterns, the adolescents' statements revealed "perceptions on damage/fear of overdose", "legal consequences", "family", "affective partners/friends" and "future perspectives". The perceptions in terms of harm and risk for health, fear of death due to cocaine overdose, weakened family relationship and legal consequences of criminal acts related to drugs were the most mentioned aspects to justify the search to reduce drugs consumption. Although literature mentions that damage perception is limited during adolescence(22), we cannot affirm whether treatment contributed to the frequent mentioning of these risk aspects. Literature also evidences, however, that knowing and observing the harm resulting from drugs use are considered protective factors for drugs use ${ }^{(23)}$.

Friends and affective partners were mentioned as stimuli to reduce drugs use, in the sense that the interviewed adolescents serve as examples. Family relations were indicated as stimuli because they are weakened, according to the adolescents, due to drugs use. It is highlighted that this may be related with the constraint the adolescents report about feeling responsible for family discord.

\section{How he reached specialized treatment}

Specialized treatment essentially started through forwarding, either judicially (associated with criminal acts or monitoring by a Child and Youth Protective Service) or by family members. Only three out of 14 interviewed adolescents spontaneously sought treatment. These facts remit to earlier discussions on damage perception (or its absence), or also to the identification of the need for specialized help regarding the drugs issue: the nonobservance of these aspects can hamper treatment success due to the lack of motivation or availability to change(24), as discussed next.

\section{Factors helping to continue treatment or reduce consumption}

The factors the adolescents reported as favorable for treatment adherence and success related to the constitution of a new relationship network without the presence of drugs users, to "strength of will", to a good relationship with professionals at the specialized service, to the existence of family support, to sports and religious practices. Also, some mentioned the importance of interrupting drugs use alone before treatment, with the maintenance of abstinence as a mere function of the latter.

The interviewees repeatedly mentioned the negative influence of friends who use drugs. In this sense, the search for a new and more protective network of relations can represent this attempt to organize one's life without the presence of drugs. Both this aspect and the "strength of will" are related with the stages of motivation to change behavior(25). According to this reference framework, the availability to change can be characterized in five motivational stages, which are succinctly described below. The first stage (precontemplation) refers to the period during which the person does not identify the problem and, thus, does not perceive the need for specialized care; this may be the phase of adolescents who were forwarded for treatment. The contemplation phase is characterized by the acknowledgement that something is wrong and needs to be solved. The preparation stage is related to the planning of some small short-term actions towards a behavioral change. The fourth stage refers to the moment when the person performs the actions he has prepared himself for with a view to solving the problem. It is marked by constant changes of reason, emotions and thoughts (adolescents who performed self-care measures related to drugs probably figure between the third and fourth stages, such as reformulating daily activities and the network of relations). Finally, the main characteristic of the last stage, maintenance, is the stabilization of the 
behavioral change, with the prevention of relapse as the main challenge. Some adolescents mentioned that they consider help as a function of treatment during this maintenance phase only.

\section{Factors hampering treatment}

Again, the group of friends was reported, but as an influence towards not continuing treatment. Another aspect mentioned, going against the "strength of will" that was indicated as necessary to keep up the treatment, was when the adolescent does not truly aim to reduce drugs consumption, which favors early abandonment, which occurs when drugs use is not perceived as a problem that needs treatment, despite its consequences.

The family's participation in treatment activities was one of the aspects the adolescents in this study strongly mentioned. The absence of this support was discussed as a determinant aspect of treatment dropout, as described in literature ${ }^{(3)}$. Other factors included accessibility of drugs, common in contexts of fun (partiers) and daily life and, finally, they mentioned possible maladaptation of specialized treatment for this population (such as a team that does not welcome and does not enhance bonding, proposed treatment activities that are not interesting for adolescents, difficult access of specialized service or functioning hours different from these adolescents' demand). These aspects, intrinsic and extrinsic to the adolescents in this study, are in line with literature findings on the factors hampering treatment adherence $^{(8-9)}$.

\section{Contributions of treatment}

For some of the adolescents in this study, their participation in the proposed treatment activities enhanced the decrease in drugs consumption or the maintenance of abstinence. For others, the support treatment provides improved self-perception and more conscious substance use. The adolescents also appointed that the treatment's contributions went beyond the issue of drugs use and were also effective to improve family relations. Based on some reports, however, we identified that treatment did not contribute as expected to reduce the drugs consumption pattern. Hence, it is important for treatment to recommend attention to the different spheres of adolescents' lives, so that they perceive the modifications and contributions it achieves, with a view to stimulating treatment continuation and effectiveness.

\section{Characteristics of an attractive/effective service}

Finally, among the different categories identified in the adolescents' statements, some refer to what they consider characteristics of attractive/effective treatment for this population. For the adolescents in this study, a service that offers treatment for adolescent drugs users should have a multidisciplinary team that has been trained to work with the demands characteristic of adolescence, that enhances dialogue, welcoming, and even comprises former drugs users who are familiar with some specific drugs experiences. Another characteristic refers to the activities treatment proposes, which should be attractive and motivating, so that, according to the adolescents, they help them to choose this treatment to the detriment of being in situations of drugs exposure. And, also, they suggested that treatment be restricted to this specific age group, without the presence of adults at the treatment site.

\section{Conclusion}

In view of the above, it can be concluded that treatment adherence for drugs abuse or addiction depends on different factors internal and external to the adolescent. Some additional aspects could be observed though, which the interviewees mentioned and which can contribute to direct therapeutic interventions aimed at improving treatment adherence and, hence, treatment effectiveness.

Treatment-related factors, such as an adequate multiprofessional team for care delivery to the adolescents, which permits bonding and welcoming of adolescents and families, enhancing their involvement in treatment activities; proposal of more interesting and motivating activities for the adolescents; presence of people in the same age range for treatment; location of specialized service (permitting easy access for the adolescents), as well as availability of welcoming hours during periods the adolescents consider "critical" with regard to drugs (such as nights and weekends) were appointed as facilitators for greater treatment adherence.

Some of the presented drugs-related aspects can be covered together with the adolescents under treatment, such as the possibility of addressing the organization of daily activities, strategies for coping with conflict situations and managing one's own feelings and the configuration of a network of healthier relations, as well as reflection together with the adolescents on their 
perspectives and life projects, which can include aspects related to education, work and personal development.

In this specialized outpatient service context, nursing professionals are fundamental, among other roles, as the reference professionals and main bond for certain service users. Thus, it is extremely relevant for them to know the demands characteristic of adolescence, especially regarding the relation with drugs, and to have skills to address the different aspects of the adolescents' lives together with them.

This research intends to contribute to other studies published in this journal regarding the understanding of the different factors that comprise the complexity of the relation between the human being and psychoactive drugs, specifically during adolescence. Further studies are needed though, to complement these findings, as these were some adolescents' opinions and perceptions, understood based on a subjective look. Although these can guide some interventions, they do not fully represent this population. Thus, we suggest other studies aimed at understanding drugs as part of adolescents' daily life, as well as aspects related to greater effectiveness of specialized treatment directed at this public.

\section{References}

1. Ministério da Saúde (BR). Secretaria Executiva. Secretaria de Atenção à Saúde. A política do Ministério da Saúde para a atenção integral a usuários de álcool e outras drogas. Brasília: Ministério da Saúde; 2003. (Série B. Textos Básicos de Saúde).

2. Lei no 10.817, de 08 de junho de 2001 (BR). Dispõe sobre a obrigatoriedade de implantação de programa de atendimento a crianças e adolescentes dependentes de álcool e outras drogas. Diário Oficial do Estado de São Paulo [internet], São Paulo, SP, 09 junho 2001 [acesso: 04 dezembro 2009]. Disponível em: http://www.legislacao.sp.gov.br/dg280202.nsf/ ae9f9e0701e533aa032572e6006cf5fd/a28d5e3751356 b3b03256d20006fe305?OpenDocument.

3. Schenker M, Minayo MCS. A importância da família no tratamento do uso abusivo de drogas: uma revisão da literatura. Cad Saúde Pública. 2004;20(3):649-59.

4. Kuntsche E, Knibbe R, Gmel G, Engels R. Who drinks and why? A review of socio-demographic, personality, and contextual issues behind the drinking motives in young people. Addict Behav. 2006;31:1844-57.

5. Rodriguez VMR, Scherer ZAP. Motivação do estudante universitário para o consumo de drogas legais. Rev. Latino-Am. Enfermagem. 2008;16(spe):572-6.
6. Matias CA. Caracterização de serviços de atendimento público aos jovens que fazem uso de drogas no município de Ribeirão Preto. [Dissertação de Mestrado] Ribeirão Preto (SP): Faculdade de Filosofia Ciências e Letras de Ribeirão Preto da Universidade de São Paulo;2007. 240 p.

7. Miller NS, Flaherty JA. Effectiveness of coerced addiction treatment (alternative consequences). A review of the clinical research. J Substance Abuse Treat. 2000;18:9-16.

8 Scaduto AA, Barbieri V. O discurso sobre a adesão de adolescentes ao tratamento da dependência química em uma instituição de saúde pública. Ciênc Saúde Colet. 2009 março-abril;14(2):605-14.

9. Ball AS, Carroll KM, Canning-Ball M, Rounsaville B]. Reasons for dropout from drug abuse treatment: symptoms, personality and motivation. Addictive Behav. Oxford, 2006;31:320-30.

10. Laudet AB, Stanick V, Sands B. What could the program have done differently? A qualitative examination of reasons for leaving outpatient treatment. J Substance Abuse Treat. 2009;37:182-90.

11. Slesnick N. Variables associated with family therapy attendance in runaway youth: Preliminary findings. Am J Fam Ther. 2001;29:411-20.

12. Bogdan RC, Biklen SK. Investigação qualitativa em educação: uma introdução à teoria e aos métodos. Portugal: Porto; 1994. 335 p.

13. Ministério da Saúde (BR). Diretrizes e normas regulamentadoras de pesquisa envolvendo seres humanos. Brasília: Conselho Nacional de Saúde. Programa Nacional de DST/AIDS; 1996.

14. Portaria GM n³36 de 19 de fevereiro de 2002. Brasília, DF. [acesso 04 dez 2009] Disponível em: http:// portal.saude.gov.br/portal/arquivos/pdf/Portaria\%20 GM\%20336-2002.pdf

15. Townsend L, Flisher AJ, King G. A systematic review of the relationship between high school dropout and substance use clinical. Clin Child Fam Psychol Rev. 2007;10(4):295-317.

16. Jinez LJ, Souza JRM, Pillon SC. Drug use and risk factors among secondary students. Rev. Latino-Am. Enfermagem. 2009;17(2):246-52.

17. Horta RL, Horta BL, Pinheiro RT, Morales B, Strey MN. Tabaco, álcool e outras drogas entre adolescentes em Pelotas Rio Grande do Sul, Brasil: uma perspectiva de gênero. Cad Saúde Pública. 2007;23(4):775-83.

18. Jesus MCG, Ferriani MGC. School as a "protective factor" against drugs: perceptions of adolescents and teachers. Rev. Latino-Am. Enfermagem. 
2008;16(spe):590-4.

19. Galduróz JCF, Noto AR, Fonseca AM, Carlini EA. $5^{\circ}$ Levantamento Nacional sobre consumo de drogas psicotrópicas entre estudantes do ensino fundamental e médio da rede pública de ensino. São Paulo: Centro Brasileiro de Informações sobre Drogas Psicotrópicas, Universidade Federal de São Paulo;2004.

20. Pratta EMM, Santos MA. Levantamento dos motivos e dos responsáveis pelo primeiro contato de adolescentes do Ensino Médio com substâncias psicoativas. SMAD, Rev. Eletrônica Saúde Mental Álcool Drog. (Ed. Port.) 2006; 2(2). [acesso $04 \mathrm{dez} 2009$ ]. Disponível em: http://pepsic.bvs-psi.org.br/scielo.php?script $=$ sci_ $_{-}$ issuetoc\&pid=1806-697620060002\&lng=pt\&nrm =iso

21. Antoniazzi AS, Dell'aglio DD, Bandeira DRA. evolução do conceito de coping: Uma revisão teórica. Estudos Psicol. 1998; 3:273-94.

22. Gil HLB, Mello DF, Ferriani MGC, Silva MAI. Perceptions of adolescents students on the consumption of drugs: a case study in Lima, Peru. Rev. Latino-Am. Enfermagem. 2008;16(spe):551-7.

23. Sanchez ZV, Oliveira LG, Nappo SA. Fatores protetores de adolescentes contra o uso de drogas com ênfase na religiosidade. Ciênc Saúde Colet. 2004;9(1):43-55.

24. McWhirter PT, Florenzano UR, Soublette MP. EI modelo transteórico y su aplicación al tratamiento de adolescentes con problemas de abuso de drogas. Adolesc Latinoam. 2002; 3(2). [acesso 4 dez 2009]. Disponível em: http://ral-adolec.bvs. br/scielo.php?script=sci_abstract \&pid=S141471302002000200006\&lng=es\&nrm=iso

25. Prochaska JO, Diclemente CC. Stages of change in the modification of problem behaviors. Progr Behav Modific. 1993; 28:183-218. 